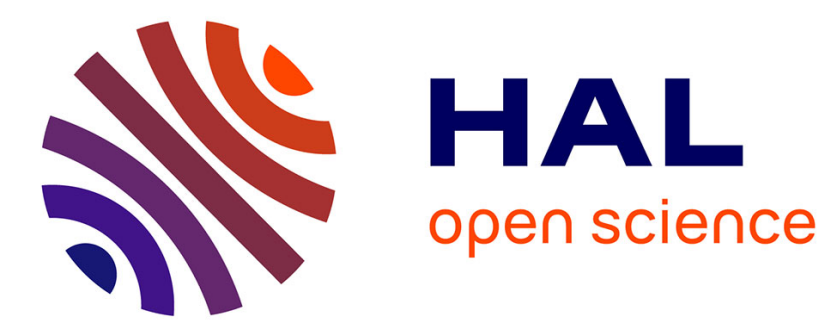

\title{
Review essay: Regional Integration, Poverty and Social Policy
}

Luk van Langenhove, Philippe de Lombaerde

\section{To cite this version:}

Luk van Langenhove, Philippe de Lombaerde. Review essay: Regional Integration, Poverty and Social Policy. Global Social Policy, 2007, 7 (3), pp.379-385. 10.1177/1468018107082240 . hal-00571810

\section{HAL Id: hal-00571810 https://hal.science/hal-00571810}

Submitted on 1 Mar 2011

HAL is a multi-disciplinary open access archive for the deposit and dissemination of scientific research documents, whether they are published or not. The documents may come from teaching and research institutions in France or abroad, or from public or private research centers.
L'archive ouverte pluridisciplinaire HAL, est destinée au dépôt et à la diffusion de documents scientifiques de niveau recherche, publiés ou non, émanant des établissements d'enseignement et de recherche français ou étrangers, des laboratoires publics ou privés. 


\title{
Regional Integration, Poverty and Social Policy
}

\author{
LUK VAN LANGENHOVE AND PHILIPPE DE LOMBAERDE \\ United Nations University, UNU - CRIS, Belgium
}

K. MALHOTRA, C. BAHADUR, S. JAHAN AND M. KEKLIK, Making Global Trade Work for People. New York: UNDP and Earthscan, 2003. 341 pp.

M. SCHIFF AND L.A. WINTERS, Regional Integration and Development. Washington: The World Bank, 2003. $321 \mathrm{pp}$.

D.W. TE VELDE (ed.), Regional Integration and Poverty. Aldershot: Ashgate, 2006. 297 pp.

Whatever position taken, there seems to be a consensus that globalization, or at least what some scholars call 'neoliberal' globalization, is affecting both economic growth and trade on the one hand, and social policy on the other hand. Globalization is affecting the social policy of states in two major ways. First, in those countries that qualify as 'welfare states', globalization threatens to weaken the existing social policy instruments aimed at the redistribution of income and the protection of the poor. Second, in the Least Developed Countries (LDCs) globalization threatens to block or counteract initiatives to establish solid social policies within those countries. But of course, there is a power-related interplay between both fears and developments. There is evidence that the rich countries (the 'North') are trying to protect their own 'acquis' by for instance blocking or limiting trade and migration from developing countries. But there is also evidence that the rich countries are combating in the South inferior labour conditions (including child labour) or industrial practices that are damaging to the environment (Deacon, 2007).

The result is a complex web of actors and regulatory initiatives that shapes globalization and the governance responses to it. Within these developments and debates, regional integration takes a special place. As a European policy 
innovation it has its origins in the political preoccupation to bring security and peace to post-war Europe, but it has developed into an economic (and political?) instrument that allows the creation of bigger 'internal' markets and thus compete better at the global level (Van Langenhove and Costea, 2007). Regional integration has in the past decades spread around the world. According to the World Trade Organization (WTO), the number of registered regional trade agreements (RTAs) has grown significantly since the early 1990s. Today more than 360 RTAs are notified to the WTO, of which almost 200 are currently in force. ${ }^{1}$

Behind this development is a growing belief that regional integration is a beneficial tool for bringing more stability and prosperity to a region. This means that at the end of the day, regional integration should have an impact on reducing poverty. But is this so? And if so, under what conditions? The debate on the contribution of regional integration to trade and growth (and poverty) echoes the broader debate on (free) trade and growth, as well as on social policy - with some claiming that national welfare systems are threatened by a 'race to the bottom' induced by regional integration. This review essay looks at the evidence for such claims by reviewing three books that all report on large-scale research projects and by linking their results to the claims of the International Labour Office (ILO) report, A Fair Globalisation: Creating Opportunities for All (World Commission on the Social Dimensions of Globalisation [WCSDG], 2004), that regional integration can only contribute to a more equitable pattern of globalization if it has a strong social dimension.

The book by Schiff and Winters reports on a major World Bank study started in 1996 on the contribution of regional integration to development and synthesizes more than a hundred research papers specifically written for this project. The book presents an impressive evaluation of the available empirical evidence on the linkages between regional integration, on the one hand, and development, on the other. All too often these linkages (and their positive signs) are taken for granted. The book discusses, in the different chapters: (1) the effects of regional integration on trade, investment, growth and location of economic activity, (2) the issue of policy integration (deep integration), (3) the contribution of regional integration to peace, and (4) the relationship between regionalism and multilateralism. The book ends with a list of 'rules of thumb for regionalism' (Chapter 9). Regarding the effect of regional integration on growth the authors' verdict is critical and clear: 'The direct evidence on regional integration agreements (RIAs) and growth is subject to some methodological reservations but is actually pretty consistent. There is little evidence that RIAs between developed countries stimulate growth, some recent evidence that NorthSouth RIAs may affect growth, and none that RIAs between developing countries do so' (p. 123). The authors find that South-South RIAs might have a 'perverse' effect on the location of economic activity, through the 
combined effect of agglomeration effects and comparative advantages, concentrating in the relatively richer countries in the arrangement and at the cost of the poorest (p. 142). ${ }^{2}$ Moving to the policy field, they are of the opinion that if there are any beneficial economic effects to be expected from RIAs at all, non-discriminatory openness will typically offer at least similar effects. They favour a multilateral trade regime that promotes liberalization and market access to foster development. They further establish that policy coordination (for example in the area of labour regulations) among developing countries offers scope for important gains, although the 'right' political and technical conditions should be in place. The authors again emphasize that this does not mean that the potential of unilateral action or multilateral regulation should be underestimated; the negotiation of global standards is the preferred route.

The book by Malhotra and others presents the conclusions of the United Nations Development Programme (UNDP) project on Trade and Sustainable Human Development, started in 2000 and supported by a grant from the Rockefeller Foundation. In Part I (four chapters) the linkages between trade and human development are discussed and a human development-oriented global trade regime is outlined. Part II (15 chapters) covers the different agreements and issues on the trade agenda systematically. As in the case of the World Bank study, a considerable number of academically rigorous background papers were written by experts. However, from the preface it is clear that the position of both groups of editors and experts in both projects do not share the same world-view. In this book, trade liberalization and market access are seen as tools that contribute to growth and development 'in specific situations and certain sectors' (p. 2). The authors of this book tend to share Rodrik's position (Rodríguez and Rodrik, 2001) that the relationship between trade and growth is not yet fully established, to say the least, whereas the authors of the World Bank study are closer to the more orthodox positions of Bhagwati, Frankel and others (Bhagwati and Srinivasan, 1999; Frankel and Romer, 1999). ${ }^{3}$ The authors of the UNDP study do not explicitly address the relationship between regional trade and (regional) growth, but they suggest that regional trade regimes should be one of the policy options for developing countries. In their view, the multilateral trade regime should be adapted in order to better take the needs of developing countries into account and maximize the possibilities for human development. It should seek 'peaceful co-existence among national practices, not harmonisation' and implement asymmetric rules favouring the weakest economies and societies. With respect to RTAs, a scenario is favoured whereby multilateral rules do provide a framework for regional agreements, but only after making the multilateral rules more flexible and developmentfriendly: ' ... WTO rules on regional agreements must be clarified to ensure that the agreements reflect human development criteria and countries enjoy the same special and differential treatment at the regional level as at the 
multilateral level' (p. 7). Countries, and by extension regions, should have sufficient policy space to design their own development (including social) policies, protect economic sectors, counter de-industrialization processes, apply conditions on foreign direct investment (FDI), etc. Multilateral institutions should do more to improve the development conditions in poor countries.

The book edited by Dirk Willem te Velde brings together the results of a research project on Regional Integration and Poverty, sponsored by the UK Department for International Development. The project focused on how regional integration can affect poverty at the country level through three main routes: (1) through the volume and poverty focus of trade, (2) through the volume and poverty focus of investment, and (3) through the volume and poverty focus of migration. Trade, investment and migration are indeed three important cross-border movements of (goods, money and people) that are affected by regional integration. But the project also looked at how 'other' routes, such as investment in infrastructure or regional socio-economic projects can affect poverty.

Part one of the book reviews the evidence available so far on regional integration and poverty and presents the outline of a conceptual framework. It indicates that there is some evidence that regional integration affects trade, FDI and migration but that the effects differ from one region to another. But there is still a lack of understanding on how and why RTAs contribute to poverty reduction. This review also makes it clear that most studies focus on trade and FDI while neglecting other dimensions of regional integration. On top of it, there is a lack of specific evidence towards which provisions in which RTAs have what effect in which country. This is because of the fact that most of the available studies deal with averages at a multi-country or multi-regional level. Hence, the choice of te Velde and his colleagues to work with case studies as well as to study in sufficient detail how specific trade and investment provisions affect trade and investment in general.

Part two deals with monitoring regional integration but focuses basically on investment-related provisions in RTAs. As to the effects of RTAs on FDI flows, the authors find that regional integration tends to raise incoming investment but that the benefits are not likely to be evenly distributed across the region.

Part three then presents two case studies in order to 'test' the conceptual framework. The case studies are Tanzania and Bolivia. In the case of Bolivia, the authors find that the stronger regional orientation of its economic activity over the previous years has had ambiguous results for poverty. The expansion of the manufacturing industry has had modest effect on workers because of wage competition. Increased investment in hydrocarbons and utilities has not had a visible impact on poverty levels. The case of Tanzania also shows limited impact of regional integration on poverty, because of the infancy of 
the integration process and the existence of structural obstacles to development and to the possibility to really take advantage of the regional integration process.

The overall conclusion of the book is that regional integration has both direct and indirect consequences for poverty but that one needs to 'remain cautious' about the three direct routes. On the other hand, the study argues that regional integration can indirectly contribute to poverty reduction via integration processes that go beyond trade and investment and include regional public goods. The te Velde study shows that RTAs have only a limited impact on poverty through migration, although it should be observed that (North-South) migration is only briefly dealt with in the book and that intra regional migration is left out of the analysis. Nevertheless, at the global policy level, the idea that migration is positive for development (and thus for poverty reduction) is still popular. The World Commission on the Social Dimension of Globalisation for instance, has argued that cross-border movements of people, well managed, enhance the social dimension of globalization and complement development policies. It also called for enhanced complementarity and coherence between different levels of governance, including the development of regional integration as a necessary but insufficient step if not complemented within a global framework. The latter point is also supported by Woolcock (2006).

Globalization presents challenges and opportunities for the developing world. Depending on formation, perspective, knowledge or ideology, different views exist on the linkages between the process of globalization, on the one hand, and economic growth, poverty and the implementation of social policies in developing countries, on the other. The three books here discussed all contribute to elevating the current debate to a more academic level, firmly grounded in empirical analysis. Regional cooperation and integration, both North-South and South-South, are thereby presented as tools and policy options with an important potential to contribute to reaching the target development variables. However, these linkages should not be taken for granted, and the advantages of multilateral regimes and the importance of unilateral actions (policies) should not be underestimated. The initiatives towards further regional cooperation and integration in different parts of the world are gradually building a regional governance level within a (flexible) global multi-level governance system. The regional level is the adequate level for the provision of certain (regional) public goods and allows a certain level of much needed institutional and policy differentiation (away from one-size-fits-all policy prescriptions) in order to reach higher levels of growth and development in the developing world. Especially among smaller developing countries, regional integration might offer a critical scale for the provision of certain public goods, for the creation of an 'internal market', for reaching a minimum level of policy autonomy, and for handling border- 
crossing problems, such as economic migration and environmental threats. There is some evidence that the regional level is indeed as the ILO Report claimed 'a stepping stone' to take advantage of global opportunities and to ensure that the benefits of globalization are fairly distributed. But an eye should be kept on the intra regional distribution of the effects of regional integration; we cannot dismiss the possibility that regional integration processes end up favouring the relatively richer and bigger players in the region in the absence of cohesion policies. Mirroring the WCSDG's conclusions, the key research and policy questions, then, are not whether but rather what kind of social policies are appropriate in the context of regional integration processes.

NOTES

1. See http://www.wto.org

2. On the issue of income convergence/divergence within RIAs, see also Villaverde (2006).

3. Rodrik was also one of the principal advisors to the UNDP study.

\section{REFERENCES}

Bhagwati, J. and Srinivasan, T.N. (1999) 'Outward-Orientation and Development: Are Revisionists Right?’, Economic Growth Center Discussion Paper 806, Yale University.

Deacon, B. (2007) Global Social Policy and Governance. London: Sage.

Frankel, J.A. and Romer, D. (1999) 'Does Trade Cause Growth?', American Economic Review 89(3): 379-99.

Rodríguez, F. and Rodrik, D. (2001) 'Trade Policy and Economic Growth: A Skeptic's Guide to the Cross-National Evidence', in B.S. Bernanke and K. Rogoff (eds) NBER Macroeconomics Annual 2000 (pp. 261-325). Cambridge: MIT Press.

Van Langenhove, L. and Costea, A.-C. (2007) 'The EU as a Global Actor and the Emergence of "Third Generation" Regionalism', in P. Foradori, P. Rosa and R. Scartezzini (eds) Managing a Multilevel Foreign Policy: The EU in International Affairs (pp. 63-86). Lanham, MD: Lexington Books.

Villaverde, J. (2006) 'Indicators of Real Economic Convergence', in P. De Lombaerde (ed.) Assessment and Measurement of Regional Integration (pp. 146-61). London: Routledge.

Woolcock, S. (ed.) (2006) Trade and Investment Rulemaking: The Role of Regional and Bilateral Agreements. Tokyo: UNU Press.

World Commission on the Social Dimensions of Globalisation (WCSDG) (2004) A Fair Globalisation: Creating Opportunities for All. Geneva: International Labour Office - World Commission on the Social Dimensions of Globalisation. 
BIOGRAPHICAL NOTE

Luk Van Langenhove is Director of United Nations University - Comparative Regional Integration Studies (UNU-CRIS) in Bruges, Belgium. Please address correspondence to Luk Van Langehove, UNU-CRIS, Grootseminarie, Potterierei 72 (second floor), 8000 Bruges, Belgium. [email: director@cris.unu.edu]

PHILIPPE DE LOMBAERDE is Research Fellow at UNU-CRIS in Bruges, Belgium. Please address correspondence to Philippe De Lombaerde, UNU-CRIS, Grootseminarie, Potterierei 72 (second floor), 8000 Bruges. [email: pdelombaerde@cris.unu.edu] 